\title{
Constructing Images, Translation and Ideology. Pablo Neruda's Canto General during the McCarthy Years in the US
}

\author{
Penelope Johnson* \\ School of Modern Languages \& Cultures \\ Durham University \\ Elvet Riverside, New Elvet, Durham DH1 3JT, UK
}

Received 04.11.2014, received in revised form 09.12.2014, accepted 26.01.2015

Translations are a form of rewriting, together with criticism, anthologies, historiography, text books, reference works, etc., all of which construct images of writers and/or their works (Bassnett and Lefevere 1998:10). Factors of a sociopolitical, ideological and/or literary nature influence this image construction process. This paper has two main aims: to explore to what extent ideological factors play a role in the image construction process and to ascertain to what extent these images are the result of complying with or going against the dominant ideology of the target culture at the time of publication. These aims will be achieved by using as a case study the translations into English of Canto general by the Chilean laureate poet Pablo Neruda (1904-1973) published in the US in 1950.

Keywords: translation, ideology, Neruda, Canto general, text selection.

Research area: philology.

In the past, as in the present, rewriters created images of a writer, a work, a period, a genre, sometimes even a whole literature. These images existed side by side with the realities they competed with, but the images always tended to reach more people than the corresponding realities did, and they most certainly do so now.

(Lefevere 1992:5)

According to Lefevere (1985, 1992, or poetological currents' in any particular culture 1982/2000) translations are a form of and the power wielded by the emerging images is rewriting, together with criticism, anthologies, historiography, text books, reference works, etc., all of which construct images of writers and/ or their works (Bassnett and Lefevere 1998:10). These rewritings 'are produced in the service, or under the constraints, of certain ideological and/ enormous (Lefevere 1992: 5).

These images may affect intercultural perceptions in several ways. On the one hand, they may comply with pre-existing conceptions that the target culture might have of the source culture, thus reinforcing such conceptions. On

(C) Siberian Federal University. All rights reserved

* Corresponding author E-mail address: penelope.johnson@durham.ac.uk 
the other hand, they may refute and threaten target culture preconceptions to the point of either changing these conceptions, or of being rejected and marginalised by readers, critics and so on. Within these two extremes there are various degrees and types of modification and engagement between the images constructed by different new translations and the preconceptions extant in the receiving culture. Factors of a sociopolitical, ideological and/or literary nature influence this image construction process. This paper focuses on ideological factors and has two main aims: to explore to what extent ideological factors play a role in the image construction process and to ascertain to what extent these images are the result of complying with or going against the dominant ideology of the target culture at the time of publication. These aims will be achieved by using as a case study the translations into English of Canto general by the Chilean laureate poet Pablo Neruda (1904-1973) published in the US in 1950. I will first describe and contextualise the source text and the target texts. This will be followed by the theoretical framework, the methods, and then a comparative analysis of the target texts before reaching the conclusions.

\section{Theoretical Framework}

Before discussing the theoretical premises that underpin this paper, certain concepts such as field, symbolic capital and ideology need to be operationalised.

The concept of field is described by Bourdieu (1990) as a historically constituted area of activity or a social space with its specific institutions and its own laws of functioning. Its structure is determined at any given moment by the relations of power and struggle between the positions the agents and institutions occupy within it (Bourdieu 1990: 87; Johnson 1993: 6). For example, in 'the field of cultural production' or, more specifically, in 'the literary field', we have institutions such as publishing houses, university presses, various academic bodies, and so on, that occupy more or less powerful positions within it and interact with each other in a constant power struggle. In the field of cultural production the agents may compete for symbolic capital, that is, the authority that recognition, consecration and prestige potentially brings (Johnson 1993:6; Bourdieu 1990: 111).

As for ideology, in this paper the concept extends beyond the 'political spheres' (CalzadaPérez 2002, Van Dijk 1998) and it is based on Hatim's (2001) definition of '[a] body of assumptions which reflect the beliefs of an individual, a group of individuals or an institution' (2001: 230). The concept relates to notions of group behaviour, discourse and ideas. Hence, depending on the size of the group (culture, subculture, society, field, etc.), several ideologies may co-exist. Some scholars have defined ideology as having a 'normative role', being 'commonsensical' (Verchueren 1999, quoted by Calzada Pérez 2002: $5)$ or as 'being regarded as the norm' (CalzadaPérez 2002: 5). However, this normative role might be better applied to the dominant ideology of a culture at any particular time as opposed to the other ideologies coexisting in the culture: an ideology which is usually taken for granted, and is, on the whole, unconscious until people are challenged by others with antagonistic ideologies (Van Dijk 1998: 98).

With regard to the theoretical framework, underpinning this paper are several premises that relate to translation, power and ideology. According to Lefevere (2000: 226) works of literature may be marginalised because they do not conform to the dominant ideology or poetics of the culture at a particular time, although, most often they are adapted to conform. For example, a text can be made to conform by omitting or not translating certain parts of that text. This has actually happened to Canto 
general, which according to de Costa (1979: 143) was 'cannibalized' into 'representative' selections both in Spanish and in translation 'partly because of its extraordinary length but mostly because of its controversial content'. This relates to what Venuti (1994) considers to be a domestication strategy with regard to text selection for translation. According to Venuti (1995) domestication is a strategy which produces a fluent and readable translation by minimising the foreign elements and, thus, creating the 'illusion of transparency'. A foreignising strategy, on the other hand, emphasises the foreign provenance of a text. Although, this does not necessarily mean literalism or a preservation of source language structures and/or lexis. The use of a foreignising strategy is 'motivated by an impulse to preserve linguistic and cultural differences by deviating from prevailing domestic values' (Venuti, 1998: 240), by using, for example, target culture marginal discourses, registers, styles, etc, by selecting to translate a text 'excluded from domestic canons' (Venuti 1995: 20), or by interpreting a foreign text in a way that is 'opposed to prevailing critical opinion' (Venuti 1998: 243), in order to shock target culture readers into realising that they are reading a translation.

Therefore a domesticating strategy would construct a representation that confirms and reinforces the stereotypical image of the source culture which already exists in the target culture, while, a foreignising strategy would perhaps create a more comprehensive representation, without necessarily complying with the stereotype (1994: 214-215). Thus, the texts selected following a domesticating strategy are usually those which can easily fit within domestic literary canons (Venuti 1998: 241). Relating this to self-translation, to be discussed briefly below, postcolonial translation scholars claim that the source text author from a non-dominant culture often writes in such a way as to conform to the dominant target culture's stereotype. As Jacquemond (1992: 154-155, also cf. Segupta 1990) claims this compliance is a way of assuring acceptance and increased sellability in the target culture. Moreover, often, being published in a 'strong' culture may be interpreted as a sign of international success (Tymozcko 1999b: 32).

Nevertheless, the situation is usually more complex that this, translators may comply with the dominant norms of the target culture at certain levels and be subversive at others, for example, by complying at the level of translation techniques but not at the level of text selection, or vice-versa. Thus, for instance, by selecting a text with a subversive content or which is written by an author who is considered to be subversive, the translator or human agents involved (whatever their translation style) may have the possibility of influencing not only the target culture literary system but also its ideological system. Moreover, according to Lefevere (1985) translation 'offers a cover for the translator to go against the dominant constraints of his or her time', since he or she is doing it in the name of a particular source text author with a particular reputation in the source culture (1985: 237-38). This opinion is also shared both by Weinberger (1999: 244) and Tymozcko (1999b: 33-34) and could actually mean that some target culture writers may have published their own translations of foreign works to subvert the dominant ideology of the target culture.

There may also be a case when an author has a certain amount of prestige or symbolic capital in his or her own country, but this prestige is not international and/or does not exist in the target culture. In this situation, translators, commentators and any other translation agents may take more liberties with this author's works than publishing agents and critics in the source culture (Bourdieu 1999: 221). This echoes and complements Lefevere's (1985: 236) claim that the strategies employed by the translators are 
affected by the degree of reputation of the source text author in the target culture. It also echoes the polysystem theory premise that when translation is a secondary activity in the target culture it has a conservative and consolidating effect, because translators tend to follow the models or norms of the target culture regarding both the process of selection of texts to be translated and the translation techniques used (Even-Zohar 2000: 195, 193).

\section{Methods}

The methods used in this paper are a comparative analysis of the text selection of the target texts published in the US in 1950. Kovala (1996) claims that the text selection process together with the use of paratextual devices (cover, illustrations, introductions, prefaces, footnotes, blurb, etc) and the use of translation techniques at the textual level, are three ways in which translation agents mediate between the source and the target culture. In other words, I will look at what sections and/or poems have been selected for translation and which ones have been rejected.

Next I will contextualise this case study by providing information on Neruda, Canto general and the socio-political and ideological situation of the US.

\section{Neruda and Canto General}

Neruda was born in 1904 in Parral, a small town in Southern Chile. He started writing poems from a very young age, winning his first literary prize in 1920 and publishing his first collection of poems, Crepusculario, in 1923. With the publication of Veinte poemas de amor $y$ una canción desesperada, the following year, 1924, his reputation as a great poet began to be established.

In 1938, just before embarking on the writing of Canto general (a long process that went from 1938 to 1950), Neruda had a major crisis, which affected his poetic and ideological development. His poetry started to change from being hermetic, neo-romantic and pessimistic, into more direct, simple and accessible verse (Feinstein 2004: 131-132). This crisis meant that in Canto general two antagonistic poetics coexist (Yurkiévich 1986: 198-216): a 'militant poetics ruled by a political, ideological and didactic intention' and a poetics which is 'mythical and metaphoric' (Yurkiévich 1986: 199). Both poetics alternate from one section to another, within a section, from one poem to another, and even within the same poem (1986: 200). Nevertheless, from 1938 literary scholars start separating Neruda into the 'poet of beauty' and the 'political poet' (Loveluck 1975:18).

In 1946, after the death of the Chilean President, Juan Antonio Ríos, Neruda started to work as 'Jefe Nacional de Propaganda' for the candidate of the Radical Party, Gabriel González Videla, who was representing a provisional coalition between right and left, 'Alianza Democrática'. González Videla became President in November 1946. However, the pressures of the Cold War were soon to be felt in Chile, and in October 1947, the president asked the Communist ministers to resign, ordered the arrest of the Communist Party leaders and put an end to Chile's diplomatic relations with the USSR, Czechoslovakia and Yugoslavia. As a reaction, Neruda accused González Videla of 'political treason' in a letter published in the newspaper El Nacional in Caracas and in January 1948 Neruda gave a lecture in the Senate called 'Yo acuso' (I accuse) against the President. Following this, the Communist Party was declared illegal and after the order for his arrest, Neruda became a 'fugitive' until February 1949 when he was able to be safely smuggled out of the country, with the first completed typescript of Canto general (this experience was to become the basis of Section X of Canto 
general, El fugitivo). This meant that much of Canto general was completed in hiding, during the months Neruda was being persecuted.

By 1950, Neruda's reputation and success as a poet had an international span. According to Feinstein (2004) ' $[\mathrm{b}] \mathrm{y}$ this time, translations of his poetry were available in languages as diverse as Korean, Vietnamese, Japanese, Arabic, Turkish, Ukranian, Uzbek, Portuguese, Slovak, Hebrew, Yiddish, Georgian, and Armenian' (2004:249). In 1950, during his life in exile, Neruda was awarded the World Peace Prize in the Second World Peace Congress held in Warsaw. He returned to Chile in 1952, when González Videla's presidency came to an end after almost three and a half years of exile. In 1952 he received the Stalin Peace Prize. As we will see, being awarded prizes by Communist countries and institutions clearly had a negative effect on Neruda's and Canto general's reception in the US.

\section{Canto General}

Canto general, a book of over 300 poems divided into fifteen sections, has two major themes: 'the history of Latin America' and 'the history of the poet' (Solá 1980: 228). In 1950 the book was published simultaneously in Mexico and in a clandestine edition in Chile. Before 1950 many loose poems and whole sections of Canto general had been published in newspapers, magazines and underground pamphlets both in Spanish and in translation. This meant that some of the sections, particularly Section II, Alturas de Macchu Picchu and Section IX, Que despierte el leñador, had acquired an autonomous fame of their own before the whole book was published.

Many consider Canto general to be amongst Neruda's greatest achievements (Pring-Mill 1975: XLI, Santí 1982: 205, Franco 1975a: 16, Solá 1980: 290 and Santí 2000: 94). Even Neruda himself called it his most 'important' work (Solá 1980: 128) and it has been one of the books by
Neruda that has been most published, translated and reviewed by the critics (Santí 2000: 61).

\section{US Sociocultural, political and literary background}

In 1948 'the centre of American politics had moved to the right' and Truman's administration shared 'the right-wing view that the CP [the Communist Party] was the organ of an international Communist conspiracy' (Heale 1990: 143). The Truman administration started to prosecute Communists under the Smith Act, which had been passed in 1940 and was now being used to outlaw the Communist Party (Heale 1990: 125-126).

In fact, the framework for investigating political dissent in the US had already been in place since 1908 (Robins 1992: 31) and the process carried out by the FBI of keeping files on writers, had started by 1911 (1992: 33), when the files on the poet Ezra Pound and the Marxist periodical, The Masses ${ }^{1}$, had started (1992: 3233). By 1919 the FBI had a list of over 60, 000 people "radically inclined" and was monitoring 471 radical periodicals both in the US and abroad (1992: 48). After 1935 there was an increase in the number of FBI files on US writers (1992: 75).

In 1947 the House of Un-American Activities Committee (HUAC), which had been set up in 1938 to uncover Communists, started to investigate Hollywood. 'The Hollywood Ten', a group of screen-writers and directors, refused to testify about their political beliefs and activities and were jailed for contempt of Congress, after they accused the HUAC of "violating their rights of freedom of speech and association' (Chafe and Stikkoff 1999: 41). The HUAC is mentioned in Canto general in Canto II of Section IX, Que despierte el leñador. This event marks the start of the 'worst red scare' in the US, which was to be known as McCarthyism (Fried 1997: 338), named after Joseph McCarthy, a Republican senator from 
Wisconsin. This red scare was arguably the worst, both because of the amount of time it lasted, from 1947 to the early Sixties and because of the effect it had on domestic and foreign policies and on American cultural and intellectual life (Shreker 1999: 65-66).

The effects of the so-called McCarthy 'witchhunts', which would last until December 1954, still lingered until the early 1960s, 'making it virtually impossible ... for most Americans to support any cause, domestic or international, that could possibly be construed as sympathetic to socialism or Communism' (Chafe and Sittkoff 1999: 4). As Schreker (1999) points out, McCarthyism meant that American politics took a turn to the right from the end of the Second World War, and so, 'middle-class Americans became social conformists' and a 'silent generation of students populated the nation's campuses' (Schreker 1999: 65). From the 1950s on, the 'Left', that is, 'a broad organised political force holding as a principle the need for far-reaching social and institutional change and consistently upholding the interests of the disadvantaged against the more powerful groups in society' (Hodgson 1999:87), no longer counted in American politics (Hodgson 1999: 86; Marwick 1998: 33).

The phenomenon of McCarthyism affected 'nearly every arena of cultural production', including publishing. Thus radical authors started to experience difficulties in getting published. Mickenberg (2006: 8) claims that after the Second World War, despite the fact that many people stopped being formally affiliated to the $\mathrm{CP}$, they were still committed to their fight for social justice. Therefore radical writers moved away from mainstream outlets for their work into other forms that escaped to a certain degree HUAC inspection, like pulp fiction and children's literature. In addition, authors such as Howard Fast, blacklisted by the FBI in the 1950s (Karolides 1998: 106), who had difficulty publishing in mainstream presses because of their known affiliations with the CP, had their own presses. (Mickenberg 2006: 4). Thus Fast's independent press, The Blue Heron Publishing Company, 'was expressly created to help victims of the blacklist' (2006: 151). However, McCarthyism also affected the sales of several 'red reading' lists (2006: 4), which appeared in mainstream and educational libraries, and radical books were banned, removed or even burned (2006: 283 , note $3,125,126)$. Thus, particularly during the 1950 s, many 'avenues of cultural production - most notably Hollywood, broadcasting, and teaching, but also much of the publishing industry, became closed to leftists' (2006: 146). From the above we can deduce that in the US there was a section of society, coexisting with the so-called anticommunist consensus of the Cold War, which was particularly receptive to Neruda's poetry and to Canto general.

\section{Text Selection}

Even though Canto general was first published in Spanish in Mexico in 1950, and English translations of selections of poems from the book have been published since 1942, it was not translated into English in its entirety until 1991. This meant that US readers have largely known the text through these selections included mainly in anthologies. Lefevere (1995: 254) claims that anthologising another literature in translation 'is never context-free and there is always an agenda hidden behind it.' Consequently, it could be argued that the translation agents involved carried out the selection of certain poems from Canto general in terms of their own political, social and/ or aesthetic ideologies (whether in a conscious and calculated manner or not), which means that different images of Neruda, Canto general, Chile and Latin America may potentially have emerged from the different target texts. Thus, depending on the subject matter of the poems selected, these images might be, on the one hand, lyrical and/or 
non-political and on the other, socially committed and/or overtly political.

To the best of my knowledge, during the 1950s, poems from Canto general translated into English only appeared in two anthologies, both published right at the beginning of the decade, in 1950, the same year that Canto general was printed in Spanish. One is Whitt Burnett's inclusion of Angel Flores' English version of the whole of Section II from Canto general, Alturas de Macchu Picchu, in the collection The World's Best published in 1950. The other exception is the pamphlet published by the Marxist press Masses and Mainstream also in 1950, entitled Let the Rail Splitter Awake and Other Poems. This anthology contains three complete sections: Section II, Alturas de Macchu Picchu (The Heights of Macchu Picchu), Section IX, Que despierte el leñador (Let the Rail Splitter Awake) and Section X, El Fugitivo (The Fugitive); and two cantos: Canto III, 'Los muertos de la Plaza (28 de enero de 1946. Santiago de Chile' ('The dead in the Square') from Section V, La arena traicionada (The Betrayed Sand); and Canto V 'A Miguel Hernández, asesinado en los presidios de España' (To Miguel Hernández murdered in the prisons of Spain) from Section XII, Los rios del canto (The rivers of the song).

\section{The World's Best}

In 1950 Neruda himself chose Section II, Alturas de Macchu Picchu, as 'representative' of his work to be included in the anthology The World's Best. Section II, Alturas de Macchu Picchu, describes the poetic persona's pilgrimage to the Inca city of Machu Picchu. It is a journey both upwards and inwards where the poetic persona finds his identity as a person belonging to the American continent. In this journey he also finds his true vocation in life as the spokesman of the people. Alturas de Macchu Picchu, first published in Spanish in 1945 was the fruit of
Neruda's visit to the site in 1943. It could be argued that the poetic change undergone by Neruda in the late 1930s is reflected in this poem. Thus, the first six of the twelve cantos that form this section of Canto general are more lyrical and hermetic than the rest, and they contain soulsearching themes, as the poetic persona reaches the summit of the site. While the last three cantos contain what could be considered to be a Marxist message. In Cantos X-XII ${ }^{2}$, the poetic persona addresses the site and demands from it to stop being a distraction and to allow him to see the conditions under which the Indians that built Macchu Picchu lived, worked and died:

Piedra en la piedra, el hombre, dónde estuvo?

Aire en el aire, el hombre, dónde estuvo?

Tiempo en el tiempo, el hombre, dónde estuvo?

...

Macchu Picchu pusiste

piedra en la piedra, y en la base, harapos?

Devuélveme el esclavo que enterraste!

Sacude de las tierras el pan duro

del miserable, muéstrame los vestidos

del siervo y su ventana.

Dime como durmió cuando vivía.

(Canto X, 305-336)

Stone upon stone: man, where was he?

Air upon air: man where was he?

Time upon time: man where was he?

...

Macchu Picchu, did you lay

stone upon stone, and at the base, a rag?

$\ldots$

Return to me the slave that you buried.

Disgorge from the earth the hard bread of the wretched, show me the garments of the serf and his window. 
Tell me how he slept when he lived

(translated by Waldeen)

He also puts himself forward as their spokesman: 'Yo vengo a hablar por vuestra boca muerta' ('Speak through my words, and my blood') (Waldeen 1950) he says in Canto XII. As Terry Eagleton (1976) claims: 'the narrative Marxism has to deliver is the story of the struggles of men and women to free themselves from certain forms of exploitation and oppression.' (1976: vii). This is what the narrator of Canto general seems to be doing particularly in Cantos X-XII of Section II.

Nevertheless, despite this political content, even the title itself as Wilson (2002:30) claims may have exotic associations. Even though Wilson (2002) does not explicitly elaborate on this claim, one could argue that the name of the Inca city that appears on the title would inevitably bring to the mind of the US reader visions of an ancient and 'exotic' culture. The selection of this particular section as representative of Neruda's work up to date may have been the result of negotiations between the translation agents involved, from both Latin America and the US (such as, for example, the publishing house, the editor, the translator and Neruda himself). The Dial Press, The World's Best publisher, tended to select award winning writers for publication. This may indicate that although they did not publish any politically overt poem, they considered Neruda and/or Alturas de Macchu Picchu sufficiently prestigious to be published by them. ${ }^{3}$

In addition, by making this selection, Neruda may have been conforming to certain stereotypes about Latin America possibly present in the US at the time, such as an image of Latin America as a mystical and mysterious culture. This selfselection by Neruda, could be considered to be a type of 'othering' or 'self-othering', that is, conforming to the image imposed by the more powerful receiver in order to be accepted.

The above seems to confirm Lefevere's (1985: 236) claim that before an author is canonised in the target culture (or at least before $\mathrm{s} /$ he has an established reputation) the translation strategies (in this case regarding text selection) conform to the dominant poetics and/or ideology of the target culture. It could then be said that in 1950 Neruda self-domesticated (Venuti 1995) by selecting Section II, Alturas de Macchu Picchu, to appear as representative of himself and Latin America in a literary anthology which allegedly included 'the world's best' literature. In other words Neruda himself may well have been using this self-domestication to ensure that the gates to the West would be open, in order to make himself known. Nevertheless, this cannot be considered to be simply a case of self-domestication. Neruda himself liked this particular poem because, as he stated in the introduction to the poem (in The World's Best), it represented his literary vocation to devote his efforts to the American continent, its people and culture.

In fact, the Marxist message present in the last cantos found its way into the US during an anti-communist Cold War climate, possibly because it is a message embedded in the distant pre-Colombian past and therefore less threatening to much of US readership in the 1950s. Therefore, Neruda may have also chosen this section because it potentially carries multiple messages, and thus it could reach US readers in general, regardless of whether these readers were communist sympathisers or not.

\section{Let the Rail Splitter Awake and Other Poems}

Regarding the other target text published in 1950. It must be said that despite the anticommunist climate in the US, it was possibly during these years that the most explicitly political 
representation of both Neruda and Canto general emerged with the publication Let the Rail Splitter Awake and Other Poems by the Marxist press, Masses and Mainstream, in 1950, of Waldeen's translation of some of the most politically overt poems and sections from the book.

Apart from Section II, Alturas de Macchu Picchu, which, as we said, has a mixture of lyrical and political passages, all the poems or sections selected to appear in the pamphlet are explicitly political. Section IX, Que despierte el leñador, is particularly anti-US, as can be seen in the sample below:

Por qué no intervienen

en Santo Domingo a defender el Occidente Mr. Vandenberg,

Mr. Armour, Mr Marshall, Mr. Hearst?

Por qué en Nicaragua el señor Presidente, despertando de noche, atormentado, tuvo que huir para morir en el destierro?

(Hay allí bananas que defender y no libertades,

y para esto basta con Somoza.)

(Canto II, 84-91)

In Santo Domingo why didn't

Mr Vandenberg, Mr Armour, Mr Marshall, Mr Hearst

intervene to defend the West?

Tormented, aroused in the night, why was the President of Nicaragua driven to flight, to death in exile?

(Bananas must be defended there, not liberties, and Somoza will suffice for this.)

(translated by Waldeen)

Here the poetic persona mentions some key figures from the US, such as general George Marshall, who conceived the Marshall Plan at the onset of the Cold War, and other magnates, and questions them about their interference in Latin America and about their support of dictators.

The poem 'A Miguel Hernández asesinado en los presidios de España' (to Miguel Hernández murdered in the prisons of Spain $)^{4}$ accuses Franco's regime in Spain and the Spanish poets who conformed to it:

Que sepan los que te mataron que pagarán con sangre.

Que sepan los que te dieron tormento que me verán un día.

Que sepan los malditos que hoy incluyen tu nombre

en sus libros, los Dámasos, los Gerardos, los hijos

de perra, silenciosos cómplices del verdugo, que no será borrado tu martirio, y tu muerte caerá sobre toda su luna de cobardes.

(Canto V, 32-38)

Let them know, the ones who killed you, that they will pay with blood.

Let them know, those who tortured you, that they will face me one day.

Let them know, the accursed, who today include your name in their books, the Dámasos and Gerardos, the damnable, silent hangman's accomplices, that your martyrdom will not be effaced, that your death

will fall across the full moon of their cowardice.

(translated by Waldeen)

There are also other poems where the poetic persona attacks or denounces the then current Chilean government of González Videla, such as the following example from Section $\mathrm{X}, E l$ fugitivo: 
Qué puedes tú, maldito, contra el aire?

Qué puedes tú, maldito, contra todo

lo que florece y surge y calla y mira,

y me espera y te juzga?

Maldito, con tus traiciones

está lo que compraste, lo que debes

regar a cada rato con monedas.

(Canto XI, 1-7).

What can you do, Traitor, against the air?

What can you do, Traitor, against all

that flowers and flourishes, is still

and watchful, that waits for me

and condemns you?

Traitor, those bought by your betrayals

must constantly be showered with coins.

(translated by Waldeen)

Despite the fact that, as we said, the title of Section II, Alturas de Macchu Picchu may potentially have exotic associations, one could argue that the inclusion in the anthology Let the Rail Splitter Awake and Other Poems of some of the most overtly political poems of Canto general, may well also help to highlight the political aspects of Alturas de Macchu Picchu. Therefore the image of Neruda, Canto general, Chile and Latin America that emerges from this selection could be mapped towards the more explicitly political end of the cline.

Masses and Mainstream was a Marxist Press that published a subscription magazine described in the back cover of the pamphlet as 'America's Foremost Marxist Cultural Monthly'. The pamphlet Let the Rail Splitter Awake and Other Poems (1950) was reprinted in 1951 and 1952 in the US. When we look at the mostly anticommunist political climate of the US during these three years, 1950-1953, the printing and reprinting of this pamphlet was undoubtedly a bold feat. Consequently, even though '[a]spects of a source text poetics or ideology can and often do condemn works to oblivion or their rejection' (Hatim 2001: 64); cf. Bruce 1995: 48-50) and a text could be rejected because of its content and/ or because of being written by a 'proscribed author' (Simms 1997: 3), the opposite could also be the case. That is, as appears to have been the case with Let the Rail Splitter Awake and Other Poems (1950), aspects of a source text poetics, ideological content and/or the fact of being written by a proscribed author could lead to a text's acceptance. In other words, it could be used by a certain interest-group to oppose a particular ruling ideology and/or poetics of the target culture (Bourdieu 1999:223; Venuti 1995; Álvarez and Vidal 1996).

The publication of this pamphlet may also serve as an example to show how cultural production does not tend to be homogeneous. In any particular field of cultural production, different groups of agents with their own competing political and literary ideologies may coexist and struggle for dominance, both within this field and also the field of power. This struggle is usually not equal because some groups have more symbolic capital and power than others. For example, in our case, US communists were a very small group and thus the struggle was very unequal. Masses and Mainstream may have used the text to raise the readership's consciousness, and possibly also as a weapon of propaganda against the conservative and anti-communist ideology of the time in the US.

Nevertheless, the selections from Canto general, published in 1950 and the subsequent silence for the rest of the decade, appear to illustrate how the process of translation is affected by the political, ideological and /or cultural conditions of the target culture. Politically and ideologically, the so-called McCarthy witch-hunts started that year, and the Cold War took a turn for the worse. The US dominant ideology became more explicitly anti-communist with regard to both 
foreign and domestic affairs. Culturally, regarding literary movements in the US, as was the case in the years just prior to 1950 , the dominant poetics still tended to emphasise form over content, disregarding extra-literary elements, which drew those poets and readers who complied with it towards 'political inertia'. These two reasons in combination may have meant that there was less incentive to write and/or read committed poetry, or to publish poems written by someone with a communist reputation like Neruda.

Hence, after these two cases there does not appear to be any published English translations of Neruda in the US, whether of Canto general or of any other work, until 1961, when Ben Belitt's anthology Selected Poems by Pablo Neruda was published by Grove Press. Possibly as the mid-1950s approached, because of the political climate, it may have been dangerous and/or perhaps not commercially viable to write or even publish translations that were too subversive to the dominant ideology. According to Felstiner (1980: 6-7) Neruda had become 'a renowned poet nearly everywhere except the United States' but 'around 1950, he was identified as a Communist and therefore alien to most of the North American public'. As we have seen, although Neruda had received several literary prizes and awards, which could be interpreted as a sign of his growing prestige, this only took place at first in Spanishspeaking and Communist countries. Thus factors of an ideological nature, such as even having been awarded prizes from Communist countries, may well have been an obstacle which prevented Neruda's reputation as a great poet to become established in the US during that decade.

\section{Conclusion}

The fact that a politicised image of Neruda and Canto general was generated from a translation that was published in the US when the anti-communist climate was stronger, could be interpreted as an illustration of the fact that it may well be as a result of the target culture undergoing extreme ideological conflict, when translation is more likely to be used as a weapon in this fight. Nevertheless, we need to take into account the fact that the readership of Let the Rail Splitter Awake and Other Poems was likely to have been much more restricted than that of The World's Best. The reason for this would have been the fact that the Dial Press founded in 1924, had by 1950 acquired a certain amount of prestige or symbolic power, as shown by the 'small but accomplished list of authors'5 it had already published, and that it continued publishing during the 1950s and 1960s, and in 2005, after a period of inactivity, the Dial Press Trade Paperback publishing program was launched. ${ }^{6}$ Whereas, the Marxist ideology of the publishing house Masses and Mainstream, went against the dominant anti-communist ideology in the US at the time. The file that the FBI had on this publishing house had started in 1911 (Robins 1992: 32-33), with The Masses. Therefore, the books published by them were also bound to be blacklisted. This may account for the fact that Masses and Mainstream only survived during the period 1948-1954. Consequently, because of all the factors mentioned above, the likelihood is that Let the Rail Splitter Awake and Other Poems (1950) had a much more restricted audience than The World's Best (1950). Therefore, we could safely say that the most prevailing image of Neruda and Canto general in the US during that time leaned more towards the non-political/ lyrical/mythical end of the cline.

Notwithstanding, the publication of this overtly political anthology may also serve as an example of how within the same society or culture, different ideologies fighting for dominance, tend to co-exist. It may well be that when one of these ideologies gains dominance, the subversive or non-dominant ideologies may use translation as a weapon in the fight, particularly, 
like in the present case, when these ideologies (as for example Marxism) have an international span. When this is the case, the non-dominant ideologies tend to get support from individuals from other cultures. Nevertheless, apart from the fact that the publication of Let the Rail Splitter Awake and Other Poems did not have a particularly extensive dissemination among US readers, this politicised anthology was an unusual event that was not repeated during the even more anti-communist climate of the US 1950s. The fact that there does not appear to be any published English translations from Canto general or from Neruda's oeuvre as a whole during 1951-1961, not even a non-political/lyrical selection, may be due to the fact that his growing prestige, both internationally and in the US, was not enough to compensate for Neruda's Communist reputation when the US anti-Communist consensus was at its height.

\footnotetext{
This was to become Masses and Mainstream, the publishers of one of the target texts.

In the Spanish publication of Canto general, roman numerals are used to numerate both sections and cantos. http://www.randomhouse.com/about/history.html (Accessed 20/9/14)

Section XII, Los ríos del canto, poem 5.

http://www.randomhouse.com/bantamdell/dialpress/dialpress_history.html_(Accessed 20/9/14)

http://www.randomhouse.com/bantamdell/dialpress/dialpress_history.html_Accessed 20/9/14)
}

\section{References}

\section{Primary Sources}

1. Neruda, Pablo (1950) Heights of Macchu Picchu, trans. Angel Flores, in Whit Burnett, ed. The World's Best. New York: Dial Press.

2. Neruda, Pablo (1950) Let the Rail Splitter Awake and Other Poems, trans. Waldeen et al. New York: Masses and Mainstream.

3. Neruda, Pablo (2000) Canto general, $7^{\text {th }}$ ed. Madrid: Cátedra.

\section{Secondary Sources}

4. Álvarez, Román and M. Carmen-África Vidal (1996) 'Translating: A Political Act' in Román Álvarez and M. Carmen-África Vidal, eds. Translation, Power, Subversion. Clevedon: Multilingual Matters.

5. Bassnett, Susan and André Lefevere (1998) 'Where are we in Translation Studies?' in Susan Bassnet and André Lefevere, eds. Constructing Cultures. Clevedon: Multilingual Matters.

6. Bourdieu, Pierre (1990) In Other Words. Standford: Standford University Press.

7. Bourdieu, Pierre (1999) 'The Social Conditions of the International Circulation of Ideas' in Shusterman, Richard, ed. Bourdieu: A Critical Reader. Oxford: Blackwell (originally published in French in 1990 'Les conditions socials de la circulation internationale des idées' Romanistische Zeitschrift für LIteraturgeschichte/Cahiers d'Histoire des Littératures Romanes 14:1/2:1-10).

8. Calzada Pérez, María (2002) 'Introduction' in María Calzada-Pérez, ed. Apropos of Ideology. Manchester: St. Jerome.

9. Chafe, Willian H and Harvard Sitkoff, eds. (1999) A History of Our Time. Readings of Postwar America. New York and Oxford: Oxford University Press.

10. De Costa, René (1979) The Poetry of Pablo Neruda. Cambridge, Mass.: Harvard University Press.

11. Eagleton, Terry (1976) Marxism and Literary Criticism. London: Methuen. 
12. Even-Zohar, Itamar (1978/1990/2000) 'The Position of Translated Literature within the Literary Polysystem' in Lawrence Venuti (ed) The Translation Studies Reader. London and New York: Routledge.

13. Feinstein, Adam (2004) Pablo Neruda: A Passion for Life. London: Bloomsbury.

14. Felstiner, John (1980) Translating Neruda: The Way to Macchu Picchu. Standford, Calif.: Standford University Press.

15. Franco, Jean (1975) 'Foreword' in Pablo Neruda Selected Poems, trans.Nathaniel Tarn, Anthony Kerrigan, W.S. Mervin and Alistair Reid. Harmondsworth: Penguin.

16. Fried, Albert (1997) Communism in America. A History in Documents. New York: Columbia University Press.

17. Hatim, Basil (2001) Teaching and Researching Translation. London and New York: Longman.

18. Heale, Michael J. (1990) American Anticommunism. Combating the Enemy Within 1830 1970. Baltimore and London: The Johns Hopkins University Press.

19. Hodson, Godfrey (1999) 'The Ideology of the Liberal Consensus' in Chafe, Willian H and Harvard Sitkoff, eds. A History of Our Time. Readings of Postwar America. New York and Oxford: Oxford University Press.

20. Jacquemond, Richard (1992) 'Translation and Cultural Hegemony: The Case of FrenchArabic Translation', in Lawrence Venuti, ed. Rethinking Translation: Discourse, Subjectivity, Ideology. London and New York: Routledge.

21. Johnson, Randal (1993) 'Editor's Introduction' in Pierre Bourdieu The Field of Cultural Production : Essays on Art and Literature. Cambridge: Polity Press.

22. Karolides, Nicholas J (1998) Literature Suppressed on Political Grounds. New York: Fact on File.

23. Kovala, Urpo (1996) 'Translations, Paratextual Mediation and Ideological Closure', Target, 8:1:119-147.

24. Lefevere, André (1985) 'Why Waste our Time on Rewrites? The Trouble with Interpretation and the Role of Rewriting in an Alternative Paradigm', in Theo Hermans, ed. The Manipulation of Literature. Studies in Literary Translation. London and Sydney: Crom Helm.

25. Hermans, ed. (1992) Translation and the Manipulation of Literary Fame. London and New York: Routledge.

26. Hermans, ed. (1995) 'German Literature for Americans 1840-1940' in Harald Kittel, ed. International Anthologies of Literature in Translation. Berlin: Schmidt.

27. Hermans, ed. (1982/2000) 'Mother Courage's Cucumbers. Text, System and Refraction in a Theory of Literature', in Lawrence Venuti, ed. The Translation Studies Reader. London and New York: Routledge. First published in 1982 in Modern Language Studies, 12: 4: 3-20.

28. Marwick, Arthur (1998) The Sixties: Cultural Revolution in Britain, France, Italy and the United States, c.1958-c.1974. New York and Oxford: Oxford University Press.

29. Mickenberg, Julia L. (2006) Learning from the Left. Children's Literature, the Cold War and Radical Politics in the United States. New York and Oxford: Oxford University Press.

30. Pring-Mill, Robert (1966) 'Preface' in Pablo Neruda, The Heights of Macchu Picchu, trans. Nathaniel Tarn. London: Cape. 
31. Robins, Natalie (1992) Alien Ink. The FBI's War on Freedom of Expression. New Brunswick: Rutgers University Press.

32. Santí, Enrico Mario (1982) Pablo Neruda: The Poetics of Prophecy. Ithaca and London: Cornell University Press.

33. Santí, Enrico Mario (2000) 'Introducción' in Pablo Neruda, Canto general, $7^{\text {th }}$ ed. Madrid: Cátedra.

34. Sengupta, Mahasweta (1990) 'Translation, Colonialism and Poetics: Rabindranath Tagore in Two Worlds', in Susan Bassnett and André Lefevere, eds. Translation, History and Culture. London and New York: Pinter Publishers.

35. Schrecker, Ellen W. (1999) 'The Age of McCarthyism' in William H. Chafe and Harvard Sitkoff eds. A History of Our Time. Readings of Postwar America. New York and Oxford: Oxford University Press.

36. Simms, Karl (1997) 'Introduction’ in Karl Simms, ed. Translating Sensitive Texts. Amsterdam: Rodopi.

37. Solá, María Magdalena (1980) Poesía y política en Pablo Neruda (análisis del "Canto General"), Río de Piedras: P.R. Editorial Universitaria.

38. Tymozcko, Maria (1999a) 'Post-colonial Writing and Literary Translation', in Susan Bassnett and Harish Trivedi, eds. Postcolonial Translation. Theory and Practice. London and New York: Routledge.

39. Van Dijk, Teun A. (1998) Ideology A Multidisciplinary Approach, London: Sage.

40. Venuti, Lawrence (1994) 'Translation and the Formation of Cultural Identities', Language and Society 1: 3: 201-217.

41. Venuti, Lawrence (1995) The Translator's Invisibility: A History of Translation. London and New York: Routledge.

42. Venuti, Lawrence (1998) The Scandals of Translation. London: Routledge.

43. Weingerger, Eliot (1999) 'The Role of the Author in Translation', in Sture Allén, ed. Translation of Poetry and Poetic Prose. London: World Scientific.

44. Wilson, Jason (2002) 'In the Translator's Workshop', Poetry London, Summer 2002: 30-32.

45. Yurkiévich, Saúl (1986) 'Mito e historia: dos generadores del Canto general' in Rodríguez Monegal, Emir and Enrico Mario Santí, eds. Pablo Neruda, Madrid: Taurus ediciones. 


\title{
Создание образов, перевод и идеология. \\ Canto general Пабло Неруды \\ в период маккартизма в США
}

\author{
Пенелопа Джонсон \\ Дарэмский университет \\ Школа современных языков и культур \\ Элвет Риверсайд, Нью Элвет, Дарэм DH1 3JT
}

\begin{abstract}
Переводы являются формой перезаписи вместе с критикой, антологиями, историографией, учебниками, справочниками и т.д., то есть со всем, что создает образы писателей и / или их paбот (Bassnett \& Lefevere 1998: 10). Факторы социально-политической, идеологической и / или литературной природы влияют на процесс создания образа. Настоящая статья имеет две основные иели: изучить, в какой степени идеологические факторы играют роль в процессе создания образа, и выяснить, в какой степени эти образы являются результатом следования или противостояния господствующей идеологии целевой культуры в момент публикации. Поставленные иели будут достигнуты на примере исследования английских переводов Canto general чилийского лауреата поэта Пабло Неруды (1904-1973), опубликованных в США в 1950 году.
\end{abstract}

Ключевые слова: перевод, идеология, Неруда, Canto general, выбор текста.

Научная специальность: 10.00.00 - филологические науки. 